\title{
The Influence of Tax Information Exchange Agreements on the Behaviour of Slovak Companies in Relation to Tax Havens
}

\author{
Michal IŠTOK ${ }^{1}$ and Marcela TAUŠOVÁ ${ }^{2}$ \\ 1 Matej Bel University in Banská Bystrica, Banská Bystrica, Slovakia, michal.istok@umb.sk \\ 2 Technical University of Košice, Košice, Slovakia, marcela.tausova@tuke.sk \\ * Corresponding author: michal.istok@umb.sk
}

\begin{abstract}
International ownership through tax havens is assumed as being one of the main reasons for applying profit-shifting methods and techniques. Since the last financial crisis, much more attention has been paid to aggressive tax planning worldwide. Tax information exchange agreements (TIEAs) are one of the major tools in combatting aggressive artificial profit-shifting to jurisdictions with zero or very low taxation. The goal of this article is to analyse the influence of concluded TIEAs in the behaviour of Slovak based companies in relation to tax havens. We analysed available data from Slovak companies with links to tax havens between 2005 and the first quarter of 2020 as provided by the company Bisnode and the list of contracting states for the purpose of the automatic information exchange according to the Act No. 359/2015 Coll. on automatic exchange of financial account information. During our analysis we primarily used regression and distribution analysis. Our results suggest that TIEAs have a statistically significant influence in slowing down the number of Slovak companies residing in tax havens. Our investigation further indicates that there are different results obtained for different categories of tax havens.
\end{abstract}

Keywords: Slovak companies; tax information exchange agreements; tax havens

JEL Classification: G38; H25; H26

\section{Introduction}

The number of Slovak companies linked to tax havens has been constantly growing since 2005. While in 2015, 1,510 Slovak companies were linked to tax havens, in the first quarter of 2020 this number has already reached 5,257 (Bisnode, 2018, 2020a). This trend as recorded by the company Bisnode is in contrast with the data available for Czech based companies, where a gradual year-on-year decrease is recorded. For example, in 2015 13,419 Czech companies were linked to tax havens, while in the first quarter of 2020 it was only 11,741 (Bisnode, 2020b). Rohan and Moravec (2017) worked out an analysis that focused on the reaction of Czech taxpayers on concluded TIEAs with preferential tax jurisdictions. They state that the concluded TIEAs play an important role as a preventive tool because the taxpayers lose their anonymity.

Nakamoto et al. (2019) identified the key companies for international profit-shifting and found that intermediate entities are based mainly in the Netherlands and the United Kingdom (jurisdictions with wide double tax treaty networks). According to the analysis of 
Janský and Palanský (2019), profits in the amount of 564.8 mil. USD were artificially transferred out of the Slovak Republic in 2016, representing a tax gap of approximately 124.3 mil. USD. Nerudová et al. (2018) pointed out the importance of corporate entities owned by shareholders through destinations outlined in the Panama papers in international tax planning. Their results further highlight the importance of establishing registries of UBOs (Ultimate Beneficial Owners) in the EU.

The Organisation for Economic Co-operation and Development (OECD) through the Global Forum on Transparency and Exchange of Information for Tax Purposes (Global Forum) is actively extending its impact globally through its Tax Information Exchange Agreement (TIEA) initiative which commenced in the early 2000s and has grown in intensity since 2009 in terms of agreements negotiated and the roll out of peer review reports for Global Forum members (Sawyer, 2011). Regarding transparency, corporate tax havens have been investigated by Bennedsen and Zeume (2018). They uncovered some interesting findings. TIEAs increase average shareholder value by $2.5 \%$. This effect is even stronger for more complex tax havens. Their research showed that some companies respond to TIEAs by moving subsidiaries to tax havens not involved in automatic tax information exchanges. They also highlight that tax havens are used for expropriation activities beyond aggressive tax planning and increased transparency is appreciated by non-controlling shareholders. AviYonah and Savir (2015) list that the U.S. have three methods for revealing taxpayers' income from tax havens - TIEAs, double tax treaties and FATCA (Foreign Account Tax Compliance Act)/IGAs (Intergovernmental Agreements). They state that both FATCA and IGAs have a tremendous psychological effect on taxpayers. Sawyer (2017) provides historical legislation on automatic information exchanges together with Hong Kong's engagement with BEPS and states that increased sophistication in international tax planning is needed compared with the past. Contrary to the mentioned authors, Kemme et al. (2017) found extremely limited evidence that TIEAs reduce tax evasion. The following table contains an overview of individual DAC directives and their characteristics.

Table 1. Overview of DAC directives. (Financial Administration of the Slovak Republic, 2020)

\begin{tabular}{|c|c|c|}
\hline Legal framework & Exchange content & Data/information (categories) \\
\hline $\begin{array}{c}\text { Directive DAC 1 } \\
\text { 2011/16/EU }\end{array}$ & Income and expenditure & $\begin{array}{c}\text { Royalties, pensions, life insurance, real } \\
\text { estate, and dependent activities }\end{array}$ \\
\hline $\begin{array}{c}\text { Directive DAC 2 CRS + FATCA } \\
\text { 2014/107/EU }\end{array}$ & Financial accounts & $\begin{array}{c}\text { Residence, account holder, account balances } \\
\text { and turnovers }\end{array}$ \\
\hline $\begin{array}{c}\text { Directive DAC 3 } \\
\text { 2015/2376/EU }\end{array}$ & Transfer pricing opinions & $\begin{array}{c}\text { Transfer pricing opinions, advance pricing } \\
\text { agreements and methods }\end{array}$ \\
\hline $\begin{array}{c}\text { Directive DAC 4 (CbCR) } \\
\text { 2016/881/EU }\end{array}$ & Multinational enterprise \\
groups & $\begin{array}{c}\text { Group members by country, main activities, } \\
\text { revenues, profits }\end{array}$ \\
\hline $\begin{array}{c}\text { Directive DAC 6 } \\
\text { 2018/822/EU }\end{array}$ & $\begin{array}{c}\text { Cross-border tax planning } \\
\text { arrangements }\end{array}$ & $\begin{array}{c}\text { Value of cross-border arrangement, } \\
\text { involved parties, measure description }\end{array}$ \\
\hline
\end{tabular}

The Ministry of Finance of the Slovak Republic publishes a list of states for the purpose of financial accounts verification according to Article 7(2) of the Act no. 359/2015 Coll. on the automatic exchange of information on financial accounts for the purposes of tax administration and on the amendment of certain acts, which are contractual party to an 
international agreement or another party with which the European Union has an agreement. At the end of 2019, this list contained 118 contracting states (Financial Administration of the Slovak Republic, 2019).

\section{Methodology}

Elaboration of this analysis is generally based on the paper of Rohan and Moravec (2017). These authors used the difference-in-differences method to predict Czech taxpayers' behaviour. Similarly, to their analysis, we also used the database provided by the company Bisnode for the overview and development of several Slovak companies linked to tax havens. As we work with the list of Slovak companies linked to tax havens as provided by Bisnode, we also took over the list of tax havens from this database and the jurisdictions were divided into three categories:

a) OFFSHORE JURISDICTIONS (OFF): Bahamas, Belize, Bermuda, British Virgin Islands, Gibraltar, Guernsey (United Kingdom), Jersey (United Kingdom), Cayman Islands, Marshall Islands, the Netherlands Antilles, Panama, Man Island, and Seychelles.

b) MIDSHORE JURISDICTIONS (MID): Hong Kong, Cyprus, Malta, United Arab Emirates, United States of America; and

c) ONSHORE JURISDICTIONS (ON): Liechtenstein, Latvia, Luxembourg, Monaco, and the Netherlands.

This categorization was made primarily based on potential benefits and often utilizing the foreign entity on the first ownership level in international holdings (e.g. Hebous, 2011; Jansky et al., 2018; Nakamoto et al., 2019). In our analysis we used the list of signed/concluded TIEAs for Slovakia. The list of valid TIEAs for individual jurisdictions was taken over from the official list as published on the website of the Financial Administration of the Slovak Republic (2019). For the default critical date (before and after the application of TIEAs) we chose the date to which the selected accounts/information started to be exchanged and verified for our analysis. To analyse and evaluate the data and trends we used mainly the regression and distribution analysis.

\section{Results}

Based on the available data and information, our analysis focuses on the period between 2005 and the first quarter of 2020. We compared behaviour trends of Slovak companies measured over the number of relocated companies to tax havens (direct equity links) before and after the effective start of the tax information exchange. We focused and analysed the average increase in the number of Slovak companies relocating to tax havens for different categories of tax havens. For most of the jurisdictions, the information started to be automatically exchanged from 2016 except for the Bahamas (2019), Hong Kong (2019), the United Arab Emirates (2019), Panama (2018), Monaco (2017) and the United States of America (2014). Our analysis consists of different steps and levels. Firstly, we focused on whether the trends development changed after the effective exchange of information for all tax haven 
groups in total. As we examined the differences in trends for all jurisdictions, 2016 was the critical date selected (according to most jurisdictions).
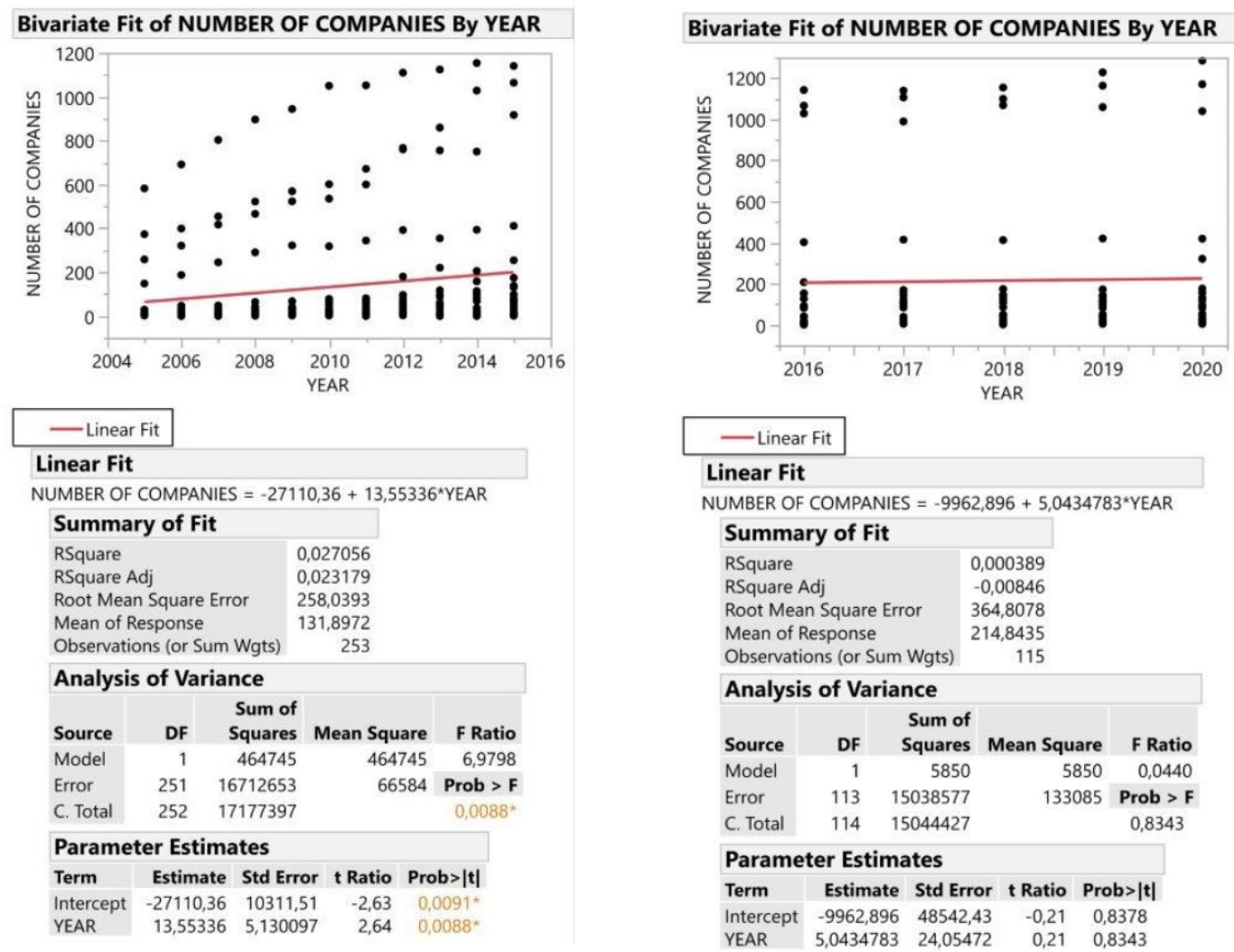

Figure 1. Regression analysis of trends for time periods 2005-2015 and 2016-2020.

The results of the regression analysis suggest that the TIEAs directly affect the average increase of new companies linked to tax havens. While in the period before the application of TIEAs the average number of new companies was 13.553, after the application of TIEAs this number dropped to 5.043. As there is a different distribution between the selected tax havens (e.g. the highest number in the first quarter was achieved by the U.S.A. $(1,285)$, the lowest figures achieved the Isle of Man (5)), we performed a distribution analysis.

For the entire monitoring period and for all countries analysed together, the results show that the average increase in the number of companies is 158 with a standard deviation of 299, which is reflected in the high values of the coefficient of variation $(\mathrm{CV})$, which represents a variation of $189 \%$. First, we began an analysis of all trends and changes for all Slovak companies linked to tax havens regardless of categorization or division. The obtained results showed that there are statistically significant changes and based on these results we performed a detailed analysis for selected groups of tax havens. For the first categorization we opted for tax haven categories as stated in the methodology (onshore, midshore and offshore). 


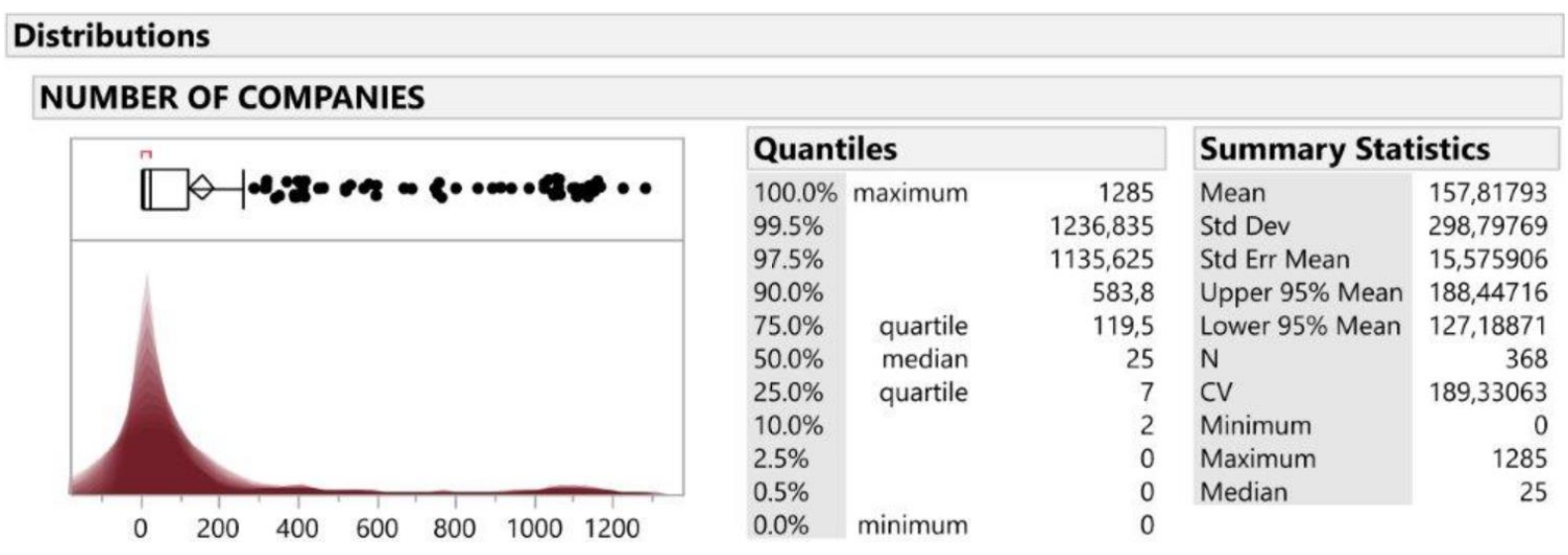

Figure 2. Distribution analysis
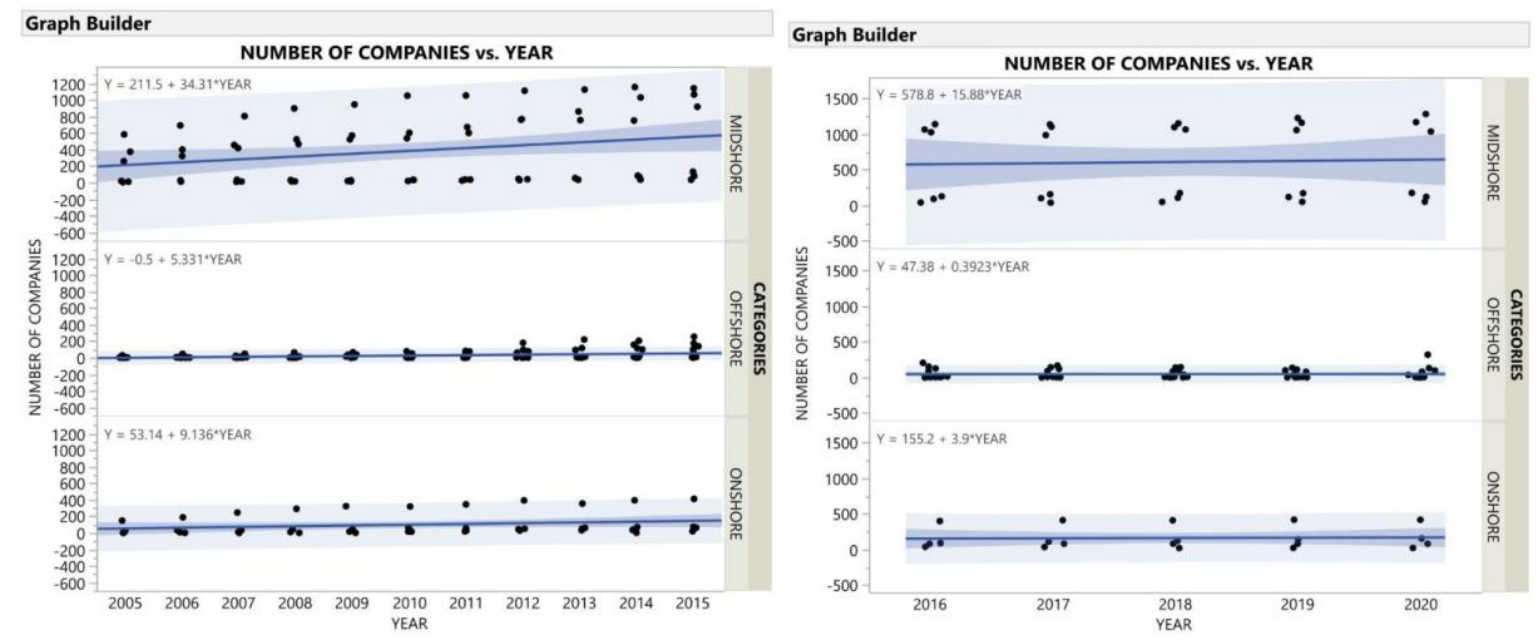

Figure 3. Trends development by tax haven groups

The results obtained suggest that the most significant slowdown in the average increase in the number of companies relocating to tax havens is recorded for the midshore category (a change from 34.31 to 15.88 , which represents a decrease of 53\%). This category is the fastest growing category before and even after the application of TIEAs. The jurisdictions from this category on the first ownership level are mainly used for tax planning activities (often linked to artificial profit-shifting). The second most significant slowdown in the average increase in the number of companies occurred in the onshore category (a change from 9.13 to 3.9, which represents a decrease of $57 \%$ ). In recent years, the slowest average increase in the number of companies has been recorded for the offshore category, while after the application of TIEAs this average increase is almost null (a change from 5.331 to 0.392 , representing a decrease of $92 \%)$. Using an offshore company in the first ownership level in international tax holding is generally not used as there is a high withholding tax $(19 \%$ or $35 \%)$ applied. The offshore companies on the first ownership level are mainly used to hide the UBO. For the second categorization we focused on the division of tax havens with or without concluded double tax treaties with the Slovak Republic. Signed bilateral tax treaties are a key assumption in the application of profit-shifting methods and techniques mainly if the company does not reside 
in another EU member state (no possibility to use EU Directives for the purpose of reducing tax or being exempt from withholding taxes).
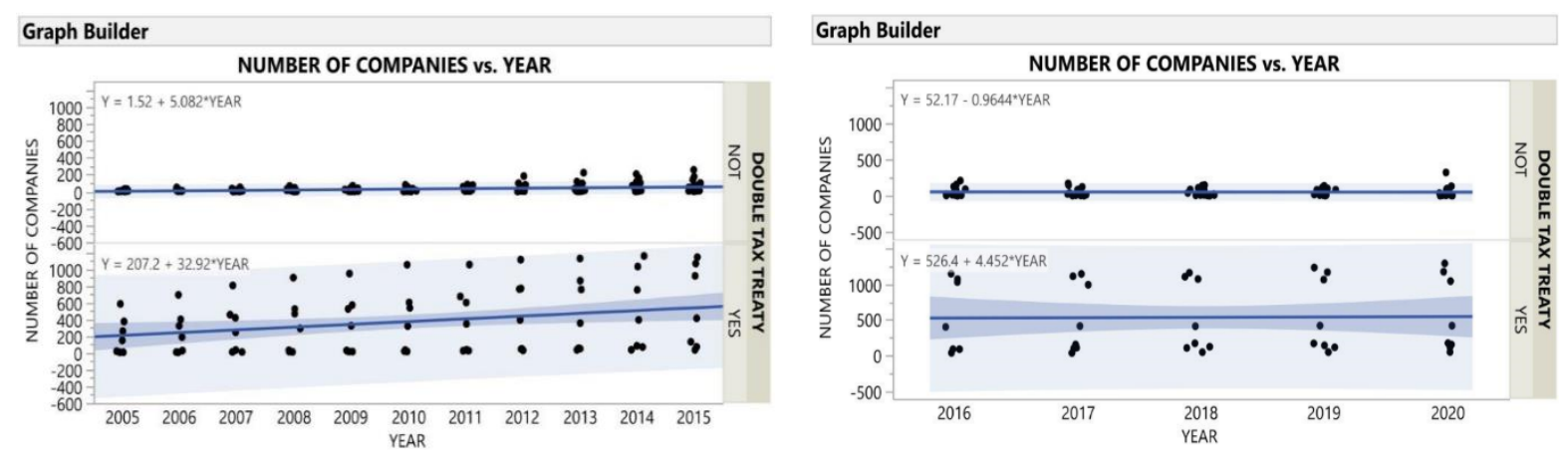

Figure 4. Trends development by double tax treaty category.

The Slovak Republic has currently no signed double tax treaties with any jurisdiction from the offshore category. This means that the average increase in the number of companies for jurisdictions with no signed double tax treaty (change from 5.082 to 0.964 ) is similar to the total offshore category. This dramatic change is recorded for the category of jurisdictions with signed double tax treaties (change from 32.92 to 4.452). Results showed that the TIEAs caused different developments (increase) of new companies in some categories of tax havens (jurisdictions) and from this we can also deduce that the use of profit shifting methods (or their combination) changed, because some profit-shifting channels/structures are often related to selected jurisdictions depending on the legislation. However, it is more likely that companies change their behaviour in applying profit-shifting methods and techniques based on actual trends in the resistance against artificial profit-shifting to zero or low-tax jurisdictions (e.g. more intensive use of new tax hybrid arrangements without using direct equity links on a first ownership level, change of tax residence or increased use of trusts and foundations). The last examined categorization is based on whether the jurisdiction is a contracting state for the purpose of TIEAs.
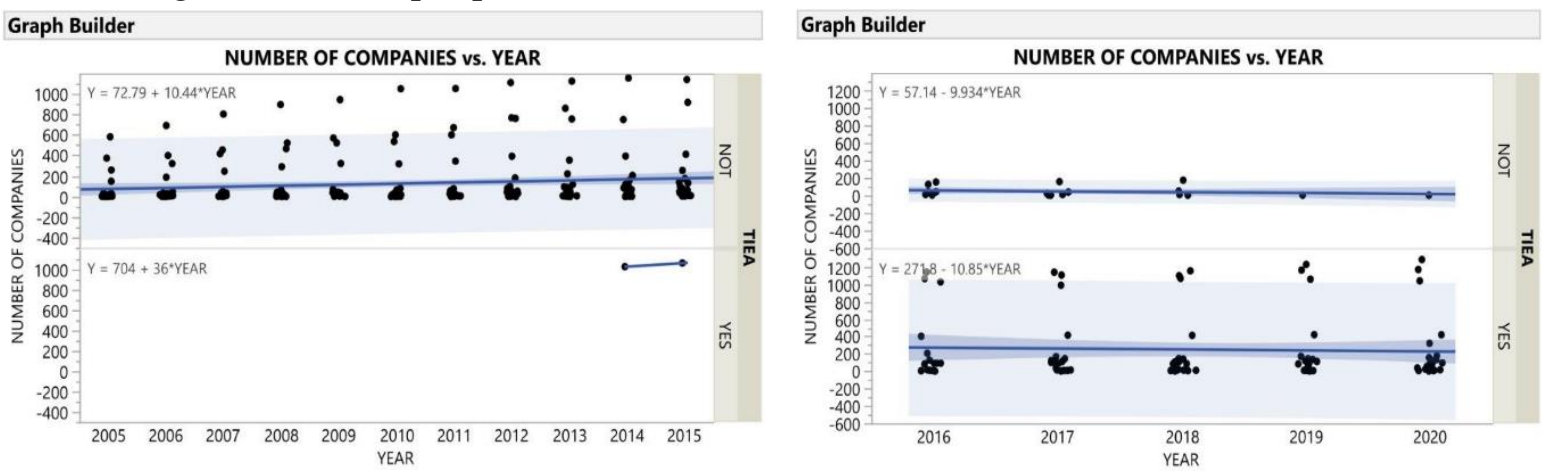

Figure 5. Trends development by TIEAs category.

The output of the regression analysis is affected by the fact that before 2016 only the United States of America was a contracting state for FATCA purposes. The obtained results again confirm that there has been a slow-down in the average increase in the number of companies linked to tax havens since 2016 - there is a recorded decline in the average increase 
from 36 to 10.85 for contracting states and from 10.44 to 9.934 for non-contracting states. The decline is much lower for non-contracting states as these jurisdictions are not practically affected by the application of TIEAs.

The output of our analysis helps to create the justified assumption that some Slovak companies respond to TIEAs by moving their subsidiaries/headquarters to jurisdictions not involved in an automatic tax information exchange. From this point of view, our results are in line with Bennedsen and Zeume (2018). In terms of TIEAs efficiency in combatting artificial profit-shifting to tax havens, the current position of the Slovak Republic can be assessed as somewhere between the trends described by Rohan and Moravec (2017) and Kemme et al. (2017). While studies from Rohan and Moravec (2017) indicate that the number of Czech companies linked to tax havens decreased by $42.8 \%$ after the application of TIEAs with these jurisdictions, the study of Kemme et al. (2017) outlines the low effectiveness of the application of TIEAs in reducing tax evasion.

The effectiveness of concluded TIEAs could differ among countries. As the automatic information exchange is a relatively new tool, there is limited academic or professional evidence on the experiences or the practical impacts. However, what can be assumed is that important roles are played by the quality of domestic tax legislation, the specific attention paid by the individual financial administrations and the quality of the business environment. To the best of our knowledge, this is the first research investigation into the influence of TIEAs on the behaviour of Slovak companies in relation to tax havens. Our research has several limitations. We analysed only the connection between Slovak companies and selected jurisdictions and only through direct equity links. As was already mentioned, there is a justified assumption that many tax hybrid arrangements are currently constructed without direct equity links on the first ownership level or constructed by using different entities (e.g. trusts, foundations or investments funds) where specific reporting rules apply. The list of tax havens used is also debatable, unquestionably certain jurisdictions are missing, e.g. the United Kingdom. The future research of this area should also be associated with an analysis of the efficiency of corporate income tax revenue collection in relation to tax havens. Currently, there has been no available research performed in the Slovak Republic in this area, but according to the study of Moravec et al. (2019), the shift of taxable profit to tax havens influences the corporate income tax collection in Slovakia (e.g. the corporate income tax efficiency for 2015 was at the level of 0.680291).

The intense struggle against artificial profit shifting to tax havens brings increased corporate (and personal) income tax revenues to a state's economy. The higher efficiency of direct income tax collection is important mainly in periods affected by crisis, such as the COVID-19 crisis for example. It can be clearly assumed (and in many cases already confirmed) that the TIEAs system is an important tool in this area and its importance will gradually increase.

\section{Conclusions}

The study confirmed the influence of concluded TIEAs in the behaviour of Slovak based companies in relation to tax havens. Statistically the application of TIEAs significantly slowed 
down the average increase in the number of Slovak companies relocating to tax havens despite a year-on-year increase in the absolute values. This trend is confirmed for all tax haven categories, but we observed many additional trend developments. The largest slowdown in the average increase of Slovak companies relocating to tax havens was recorded in the midshore category, where the average number after the application of TIEAs decreased from 34.31 to 15.88 per year, a difference of 18.43 for newly relocated companies. The next largest difference we observed was in the onshore category with 5.236. Following on from that we come to the offshore category with a slower 4.938 average increase in the number of companies. The midshore category has recorded the highest average increase of relocated companies even after the application of TIEAs, from which it can be assumed that tax planning is the most common incentive in the relocation of new companies to tax havens. In the application of TIEAs, we also see a slowdown in the average increase recorded for double tax treaty categories of tax havens, where the largest slowdown in the average increase was recorded for the category of jurisdictions with signed double tax treaties (28.468) and less so for the no double tax treaty category (4.117). The last differences observed were for contracting and non-contracting states (involved or not involved in a system with TIEAs). The jurisdictions which have signed up to TIEAs during the investigated period recorded a threefold average increase decline, while the average increase rate for jurisdictions outside the TIEAs system remained almost unchanged.

\section{References}

Avi-Yonah, R. S., \& Savir, G. (2015). Find it and tax it: From TIEAs to IGAs (Research Paper No. 443). University of Michigan Public Law. https://doi.org/10.2139/ssrn.2567646

Bennedsen, M., \& Zeume, S. (2018). Corporate Tax Havens and Transparency. The Review of Financial Studies, 31(4), 1221-1264. https://doi.org/10.1093/rfs/hhx122

Bisnode. (2018). Z daňových rajov je riadený historicky najväčší počet firiem. https://www.bisnode.sk/o-bisnode/onas/novinky/z-danovych-rajov-je-riadeny-historicky-najviac-firiem/

Bisnode. (2020a). Počet našich firiem v daňových rajoch prekročil hranicu 5-tisíc. https://www.bisnode.sk/obisnode/o-nas/novinky/pocet-nasich-firiem-v-danovych-rajoch-prekrocil-hranicu-5-tisic/

Bisnode. (2020b). Odliv firem z daňových ráju mírně zpomalil. Marshallovy ostrovy se vymykají statistikám. https://www.bisnode.cz/o-bisnode/o-nas/novinky/odliv-firem-z-danovych-raju-mirne-zpomalil/

Financial Administration of the Slovak Republic. (2019). Zoznam zmluvných štátov na účely preverovania finančných účtov podl'a zákona č. 359/2015 Z. z. o automatickej výmene informácií o finančných účtoch na účely správy danía o zmene a doplnení niektorých zákonov. https://www.financnasprava.sk/_img/pfsedit/

Dokumenty_PFS/Infoservis/AVI/2019/2019.12.06_zoz_stat_prev_uct.pdf

Financial Administration of the Slovak Republic. (2020). AVI - Automatická výmena informácií. https://www.financnasprava.sk/sk/infoservis/avi/_1.

Hebous, S. (2011). Money at the Docks of Tax Havens: A Guide (Working Paper Series No. 3587). CESifo. https://papers.ssrn.com/sol3/papers.cfm?abstract_id=1934164

Jansky, P., Meinzer, M., \& Palansky, M. (2018). Is Panama Really Your Tax Haven? Secrecy Jurisdictions and the Countries They Harm (Working Paper: 23/2018). IES.

https://papers.ssrn.com/sol3/papers.cfm?abstract_id=3267366.

Janský, P., \& Palanský, M. (2019). Estimating the scale of profit shifting and tax revenue losses related to foreign direct investment. International Tax and Public Finance, 26, 1048-1103. https://doi.org/10.35188/UNUWIDER/2018/463-6

Kemme, D. M., Parikh, B., \& Steigner, T. (2017). Tax Havens, Tax Evasion and Tax Information Exchange Agreements in the OECD. European Financial Management, 23(3), 519-542. https://doi.org/10.1111/eufm.12118 
Moravec, L., Rohan, J., \& Hinke, J. (2019). Estimation of international tax planning impact on corporate tax gap in the Czech Republic. EEM Ekonomie a Management, 22(1), 157-171. https://doi.org/10.15240/tul/001/2019-1011

Nakamoto, T., Chakraborty, A., \& Ikeda, Y. (2019). Identification of key companies for international profit shifting in the Global Ownership Network. Applied Network Science, 58(4), 1-26. https://doi.org/10.1007/s41109-019-0158-8

Nerudová, D., Solilová, V., Litzman, M., \& Janský, P. (2018). International tax planning within the structure of corporate entities owned by the shareholder individuals through Panama Papers destinations. Development Policy Review, 38(1), 124-139. https://doi.org/10.1556/204.2020.00026

Rohan, J., \& Moravec, L. (2017). Tax information exchange influence on Czech based companies' behavior in relation to tax havens. Acta Universitatis Agriculturae et Silviculturae Mendelianae Brunesis, 65(2), 721-726. https://doi.org/10.11118/actaun20176502072

Sawyer, A. (2011). The OECD's tax information exchange agreements an example of (in)effective global governance? Journal of Applied Law and Policy, 41-54.

Sawyer, A. (2017). An update on Hong Kong's exchange of information developments and engaging in with BEPS. Asia Pacific Law Review, 25(2), 170-189. https://doi.org/10.1080/10192557.2017.1396663 